\title{
Measurement and Improvement Analysis of Applications and Services with IT Balanced Scorecard on Online Transportation in Bandung
}

\author{
Bima Adhiguna \\ Magister Management \\ Universitas Komputer Indonesia \\ Bandung, Indonesia \\ bima26.adhiguna@gmail.com
}

\begin{abstract}
Research aims to measure and improve services and applications to the performance of online transportation companies, namely the IT Balanced Scorecard. Measurement and analysis of data using the R-Commander application by measuring and analyzing several parameters in it. The result is that the data is valid because $r$ (item, total) for each question 0.6. Whereasfor the classical assumption test, that is, no problemwith multicollinearity, there is nopositive and negative autocorrelation, and there is no problem with heteroscedasticity, but research datais not normally distributed because the data in the questionnaire is ordinal. Furthermore,for thelinear test and descriptive tests, it explainsthat thereis apositive influence between $X I$ and $X 2$ onY andthe results of the respondents areincluded inthegood category.So that it can be concluded that the service and application of the balanced scorecard is currentlyin the feasible category, there is a aresitive influence of services and applications onit balanced scorecardso that if an online transportation company wants to improve theperformance of the company can use these references.
\end{abstract}

Keywords - service, application, measurement, improvement, IT Balanced Scorecard

\section{INTRODUCTION}

Measurement and improvement of services, applications and it balanced scorecard on the use of online transportation in Bandung is needed. Because, at this time users of online transportation services have been very numerous. However, there are still perceived problems, such as the YLKI survey which found consumer disappointment or complaints about online transportation services. The complaint can be divided into 2 types, namely related to services and applications.

Service measurement by identifying five gaps that cause unsuccessful delivery [1].
Dedi Sulistiyo S

Magister Management

Universitas Komputer Indonesia

Bandung, Indonesia

dedi@unikom.ac.id

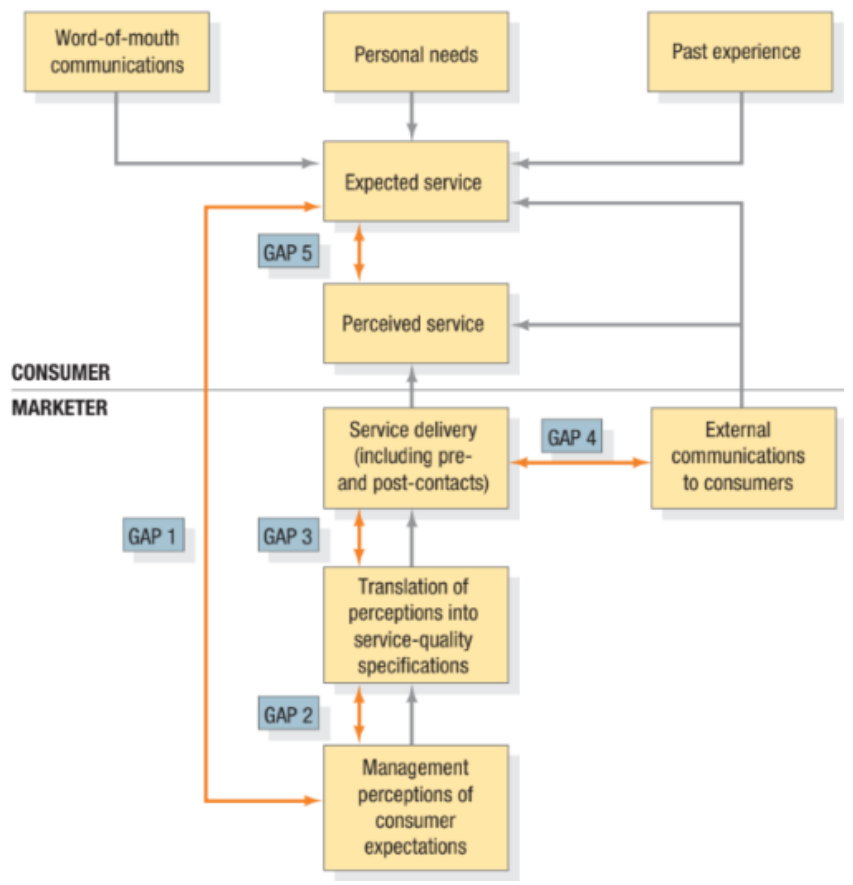

PICTURE 1. Service-Quality Model [1]

While the application measurement is defines five characteristics related to outcomes of interaction with a system [2].

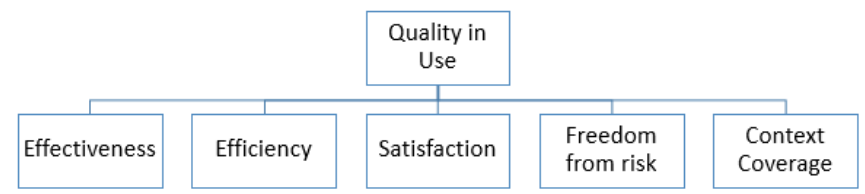

PICTURE 2. Quality in Use Model

In previous studies, it was never discussed about the measurement and improvement of services and applications in online transportation systems. However, on other systems, such as Rohmad Dwi Jayanto and Handaru Jati, which discussed about quality evaluation of dictionary network mobile application on android platform with standard ISO/ IEC 25010 [3]; Gunardi, Dedi Sulistiyo S., and Suryana Taryana discussed about strategic map proposal using CSF and IT Balanced Scorecard [4]; Cindi Wulandari, Lin Yan Syah, and Leon Andretti A. discussed about analysis of 
satisfaction level of IT services [5]; Anal Acharya and Devadatta Sinha discussed about Assessing the Quality of M-Learning Systems using ISO/IEC 25010 [6]; and Indra Balachandran and Ibrahim Bin Hamzah discussed about influence of customer satisfaction on ride sharing services in Malaysia [7].

Therefore, researchers are interested in conducting research on the measurement and improvement of services and applications against the use of online transportation to the IT balanced scorecard.

\section{METHOD}

\section{A. Validity and Reliability Test}

First is Validity Test is done to see how far the score / value / size obtained actually states the measurement / observation results. While the reliability test is done to show how far a measuring device can be trusted or reliable. Each measuring device should have the ability to provide measurement results that are relatively consistent over time. Both tests are carried out on each question on the questionnaire distributed to respondents.

\section{B. Classical Asumption Test}

There is some Classical Assumption Test.

1) Multicollinearity Test is used to determine existence of high correlation between variables in a multiple regression model. If there is a high correlation between the independent variables, then relation between them of the dependent variable will be disrupted [7]. Multicollinearity testing can be done by looking at value of Variance Inflation Factors (VIF). If the value of VIF $<10$ then not multicollinearity, and if the value of VIF $>10$ then there is multicollinearity.

2) Autocorrelation Test: is used to see that there is a linear relation between the errors on a series of observations, sorted by time (time series) [7]. Testing can use the Durbin Watson (DW) test method. If the value of DW < Durbin Lower (dL) then there is positive autocorrelation, and if the value of $4-\mathrm{DW}<$ Durbin Upper (dU) then there is negative autocorrelation

3) Heteroscedasticy Test: is used to test there is a regression model residual variance inequality from one observation to another observation. Regression formula obtained by assuming confounding variables (error) has a constant residual variance (range of errors approximately equal). Heteroscedasticity occurs if there is residual variance is not constant [7]. If the value of probability < alpha (0.05) then there is problem of heteroscedasticy, and If the value of probability > alpha (0.05) then there is no problem of heteroscedasticy. The regression model to be good if there is no problem of heteroscedasticy.

4) Normality Test: a form of testing about the distribution of data. The purpose is to find out whether the data taken is normally distributed data. The normality testing can be done by Shapiro Wilk test. If p-value < alpha (0.05) then data is not normally distributed, and if If p-value > alpha (0.05) then data is normally distributed

5) Linearity Test: is used to determine whether two or more variables have a significant linear relationship or not. The results of these tests can then be used to help make decisions in determining the regression model that will be used appropriately [7].

\section{Descriptive Test}

Descriptive analysis is used to determine the characteristics of the variables studied from the primary data obtained in the research. Descriptive analysis helps in answering research hypotheses that have been determined, such as:

Ho : $\mathrm{p}=0$, Service, Application and IT Balanced Scorecard not in a feasible category for consumers of online transportation (Grab) in Bandung

Ho : $p \neq 0$, Service, Application and IT Balanced Scorecard in a feasible category for consumers of online transportation (Grab) in Bandung.

In this study, descriptive analysis was carried out by examining the feasibility of the variables studied. There are five categories of feasibility categories [8], can be seen in Table 1 .

\section{TABLE 1. FEASIBILITY CATEGORY}

\begin{tabular}{|c|c|c|}
\hline Number & Percentage (\%) & Feasibility Category \\
\hline 1. & $<21 \%$ & Very Unfeasible \\
\hline 2. & $21 \%-40 \%$ & Not feasible \\
\hline 3. & $41 \%-60 \%$ & Decent enough \\
\hline 4. & $61 \%-80 \%$ & Feasible \\
\hline 5. & $81 \%-100 \%$ & Very Feasible \\
\hline
\end{tabular}

\section{RESULTS AND DISCUSSION}

In this research, data were obtained from questionnaires distributed to 100 online grab users. Data is tested using the $\mathrm{R}$-commander application. R-commander is a graphical user interface (GUI) for the R programming language that can be used for statistical analysis.

\section{A. Result of Validity and Reliability Test}

The results of the validity test for each questions can be seen in Table 2:

TABLE 2. RESULT OF VALIDITY TEST

\begin{tabular}{|l|c|c|}
\hline \multicolumn{1}{|c|}{ Questions } & r(item, total) & r-tabel \\
\hline Question 1 & 0.3478 & 0.1654 \\
\hline Question 2 & 0.3894 & 0.1654 \\
\hline Question 3 & 0.4596 & 0.1654 \\
\hline Question 4 & 0.5194 & 0.1654 \\
\hline Question 5 & 0.5093 & 0.1654 \\
\hline Question 6 & 0.4935 & 0.1654 \\
\hline Question 7 & 0.3627 & 0.1654 \\
\hline Question 8 & 0.4068 & 0.1654 \\
\hline Question 9 & 0.6239 & 0.1654 \\
\hline Question 10 & 0.3459 & 0.1654 \\
\hline Question 11 & 0.4087 & 0.1654 \\
\hline Question 12 & 0.5047 & 0.1654 \\
\hline Question 13 & 0.3695 & 0.1654 \\
\hline Question 14 & 0.4136 & 0.1654 \\
\hline Question 15 & 0.5548 & 0.1654 \\
\hline Question 16 & 0.5181 & 0.1654 \\
\hline Question 17 & 0.2211 & 0.1654 \\
\hline Question 18 & 0.3459 & 0.1654 \\
\hline Question 19 & 0.2532 & 0.1654 \\
\hline Question 20 & 0.1962 & 0.1654 \\
\hline Question 21 & 0.5164 & 0.1654 \\
\hline Question 22 & 0.6149 & 0.1654 \\
\hline Question 23 & 0.5682 & 0.1654 \\
\hline Question 24 & 0.4974 & 0.1654 \\
\hline Question 25 & 0.5480 & 0.1654 \\
\hline
\end{tabular}




\begin{tabular}{|l|l|l|}
\hline Question 26 & 0.3876 & 0.1654 \\
\hline Question 27 & 0.2397 & 0.1654 \\
\hline Question 28 & 0.1727 & 0.1654 \\
\hline
\end{tabular}

The validity of each indicator can be measured through the numbers which are stated in the box of Item Total Statistic, referring to the column named Corrected Item Total Correlation. The values of each indicator from the independent and dependent variables have to be bigger than the numbers in the $r$ table [9]. Based on the output of results in Table 1, show that the value of $r$ (item, total) for each questions $<\mathrm{r}$ table, so it can be concluded that the research data is valid.

Then, the results of the reliability test for each questions can be seen in Table 3:

\section{TABLE 3. RESULT OF RELIABILITY TEST}

\begin{tabular}{|l|l|l|l|}
\hline \multicolumn{1}{|c|}{ Questions } & Alpha & Questions & Alpha \\
\hline Question 1 & 0.8556 & Question 15 & 0.8500 \\
\hline Question 2 & 0.8547 & Question 16 & 0.8511 \\
\hline Question 3 & 0.8523 & Question 17 & 0.8589 \\
\hline Question 4 & 0.8507 & Question 18 & 0.8560 \\
\hline Question 5 & 0.8514 & Question 19 & 0.8588 \\
\hline Question 6 & 0.8521 & Question 20 & 0.8609 \\
\hline Question 7 & 0.8551 & Question 21 & 0.8505 \\
\hline Question 8 & 0.8541 & Question 22 & 0.8489 \\
\hline Question 9 & 0.8489 & Question 23 & 0.8499 \\
\hline Question 10 & 0.8556 & Question 24 & 0.8522 \\
\hline Question 11 & 0.8540 & Question 25 & 0.8511 \\
\hline Question 12 & 0.8514 & Question 26 & 0.8544 \\
\hline Question 13 & 0.8550 & Question 27 & 0.8638 \\
\hline Question 14 & 0.8541 & Question 28 & 0.8694 \\
\hline
\end{tabular}

According to Ghozali (2001), a variable is considered reliable if it scored $>0.60$. When the score of its Cronbach Alpha test gets closer to 1 , it is more reliable [9]. Based on the output of results in Table 2, show that the value of alpha for each questions $>0.6$, so it can be concluded that the research data is reliable.

\section{B. Results of Classical Assumption Test}

1) Multicollinearity Test.

The results of the VIF value is 1.298834 . VIF $<10$, so it can be concluded that there is no problem with multicollinearity. If the VIF value is greater than 10 value, the data is considered Multicollinearity and which indicates that this independent variable should be removed from the analysis [9].

2) Autocorrelation Test.

The results of the Durbin Watson can be seen in Table 4.

\section{TABLE 4. RESULT OF DURBIN WATSON}

\begin{tabular}{|c|c|}
\hline Durbin-Watson (D) & 1.8828 \\
\hline p-value & 0.2769 \\
\hline DL & 1.63369 \\
\hline DU & 1.71517 \\
\hline
\end{tabular}

Based on the output of results in Table 3, D > dL and 4 $\mathrm{D}>\mathrm{dU}$ so it can be concluded that there is no positive autocorrelation and there is no negative autocorrelation. There is no positive and negative autocorrelation because the data is not time series data. Autocorrelation test is only performed on the time series data, so in this study is not necessary to autocorrelation testing [7].

3) Heteroscedasticy Test.

Heteroscedasticy Test using Breusch-Pagan and the results can be seen in Table 5:

\section{TABLE 5. RESULT OF HETEROSCEDASTICY}

\begin{tabular}{|c|c|}
\hline Breusch-Pagan & 0.031909 \\
\hline p-value & 0.8582 \\
\hline
\end{tabular}

Based on the output of results in Table 4, sow tat the value of $p$-value $>$ alpha $(0.05)$, so it can be conclude that there is no problem with heteroscedasticy.

4) Normality Test.

The results of normality test can be seen in Table 6 .

TABLE 6. RESULT OF NORMALITY TEST

\begin{tabular}{|c|l|c|}
\hline Variabel & \multicolumn{1}{|c|}{$\begin{array}{c}\text { Sub } \\
\text { Variabel }\end{array}$} & P-Value \\
\hline \multirow{4}{*}{$\begin{array}{c}\text { Services } \\
(\mathrm{X} 1)\end{array}$} & $\mathrm{X} 1.1$ & $3.084 \mathrm{e}-13$ \\
\cline { 2 - 3 } & $\mathrm{X} 1.2$ & $7.349 \mathrm{e}-10$ \\
\cline { 2 - 3 } & $\mathrm{X} 1.3$ & $2.379 \mathrm{e}-11$ \\
\cline { 2 - 3 } & $\mathrm{X} 1.4$ & $5.389 \mathrm{e}-10$ \\
\cline { 2 - 3 } & $\mathrm{X} 1.5$ & $7.03 \mathrm{e}-12$ \\
\hline \multirow{4}{*}{$\begin{array}{c}\text { Application } \\
(\mathrm{X} 2)\end{array}$} & $\mathrm{X} 2.1$ & $3.642 \mathrm{e}-11$ \\
\cline { 2 - 3 } & $\mathrm{X} 2.2$ & $4.025 \mathrm{e}-11$ \\
\cline { 2 - 3 } & $\mathrm{X} 2.3$ & $4.214 \mathrm{e}-10$ \\
\cline { 2 - 3 } & $\mathrm{X} 2.4$ & $7.155 \mathrm{e}-10$ \\
\cline { 2 - 3 } & $\mathrm{X} 2.5$ & 0.0000001776 \\
\hline \multirow{3}{*}{$\begin{array}{c}\text { IT Balanced } \\
\text { Scorecard } \\
(Y)\end{array}$} & $\mathrm{Y} 1$ & $1.006 \mathrm{e}-10$ \\
\cline { 2 - 3 } & $\mathrm{Y} 2$ & $3.286 \mathrm{e}-12$ \\
\cline { 2 - 3 } & $\mathrm{Y} 3$ & $1.459 \mathrm{e}-11$ \\
\cline { 2 - 3 } & $\mathrm{Y} 4$ & 0.0000006599 \\
\hline
\end{tabular}

Based on the output of results in Table 5, p-value < alpha (0.05) so it can be conclude that the research data is not normally distributed. If the data is not normally distributed, then one kind of the way to overcome that is to use a device (method or model) that does not require assumption of normality [7]. Because data in questionnaire is ordinal. Nonparametric test is a mathematical model does not require the assumption of normality, so in this study used Nonparametric test for studying.

5) Linearity Test.

The results of linear model can be seen in Table 7 .

TABLE 7. RESULT OF LINIER MODEL

\begin{tabular}{|c|c|c|}
\hline & Estimate & Std. Error \\
\hline (Intercept) & 1.16437 & 0.44815 \\
\hline $\mathrm{X} 1$ & 0.45281 & 0.10300 \\
\hline $\mathrm{X} 2$ & 0.23642 & 0.09365 \\
\hline
\end{tabular}

These results show the linear regression model of the relationship between $\mathrm{X} 1$ that is gap and X2 application 
to $\mathrm{Y}$ which is the IT Balanced Scorecard based on sample data.

$$
\mathrm{Y}=1.16437+0.45281 \mathrm{X} 1+0.23642 \mathrm{X} 2+0.44815
$$

The linear regression model explains that there is a positive influence between XI and X2 on Y. The value of $\beta_{1}$ of 0.45281 can be interpreted as an average increase of $\mathrm{X} 1$ and the value of $\beta_{2}$ of 0.23642 can be interpreted as an average increase of $\mathrm{X} 2$.

\section{Results of Descriptive Test}

Based on the results of the descriptive test, the average value percentage of the questionnaire for the service variable is $72.26 \%$ which is in the feasible category, can be seen in Table 8.

\section{TABLE 8. RESULT OF SERVICE DESCRIPTIVE TEST}

\begin{tabular}{|c|c|c|c|c|c|}
\hline Question & N & Min & Max & Mean & Percentage \\
\hline Question 1 & 100 & 2 & 5 & 3.76 & $75.2 \%$ \\
\hline Question 2 & 100 & 2 & 5 & 3.61 & $72.2 \%$ \\
\hline Question 3 & 100 & 1 & 5 & 3.26 & $65.2 \%$ \\
\hline Question 4 & 100 & 2 & 5 & 3.44 & $68.8 \%$ \\
\hline Question 5 & 100 & 2 & 5 & 3.55 & $71 \%$ \\
\hline Question 6 & 100 & 2 & 5 & 3.75 & $75 \%$ \\
\hline Question 7 & 100 & 2 & 5 & 3.62 & $72.4 \%$ \\
\hline Question 8 & 100 & 2 & 5 & 3.52 & $70.4 \%$ \\
\hline Question 9 & 100 & 2 & 5 & 3.67 & $73.4 \%$ \\
\hline Question 10 & 100 & 2 & 5 & 3.95 & $79 \%$ \\
\hline & & & 3.613 & $72.26 \%$ \\
\cline { 2 - 5 }
\end{tabular}

While for the application variable, the average value percentage of the questionnaire is $69.2 \%$ where the entry is also in the feasible category, can be seen in Table 9.

\section{TABLE 9. RESULT OF APPLICATION DESCRIPTION} TEST

\begin{tabular}{|c|c|c|c|c|c|}
\hline Question & N & Min & Max & Mean & Pecentage \\
\hline Question 11 & 100 & 2 & 5 & 3.56 & $71.2 \%$ \\
\hline Question 12 & 100 & 2 & 5 & 3.62 & $72.4 \%$ \\
\hline Question 13 & 100 & 1 & 5 & 3.19 & $63.8 \%$ \\
\hline Question 14 & 100 & 2 & 5 & 3.98 & $79.6 \%$ \\
\hline Question 15 & 100 & 2 & 5 & 3.92 & $78.4 \%$ \\
\hline Question 16 & 100 & 2 & 5 & 3.72 & $74.4 \%$ \\
\hline Question 17 & 100 & 1 & 5 & 3.16 & $63.2 \%$ \\
\hline Question 18 & 100 & 1 & 5 & 3.22 & $64.4 \%$ \\
\hline Question 19 & 100 & 1 & 5 & 3.21 & $64.2 \%$ \\
\hline Question 20 & 100 & 1 & 5 & 3.02 & $60.4 \%$ \\
\hline
\end{tabular}

Then for the balanced scorecard variable obtained the average value percentage of the questionnaire is $70.2 \%$ which is in the feasible category, can be seen in Table 10.

TABLE 10. RESULT OF IT BSC DESCRIPTIVE TEST

\begin{tabular}{|c|c|c|c|c|c|}
\hline Question & N & Min & Max & Mean & Percentage \\
\hline Question 21 & 100 & 1 & 5 & 3.49 & $69.8 \%$ \\
\hline Question 22 & 100 & 2 & 5 & 3.76 & $75.2 \%$ \\
\hline Question 23 & 100 & 2 & 5 & 3.87 & $77.4 \%$ \\
\hline Question 24 & 100 & 2 & 5 & 3.78 & $75.6 \%$ \\
\hline Question 25 & 100 & 2 & 5 & 3.54 & $70.8 \%$ \\
\hline Question 26 & 100 & 2 & 5 & 3.61 & $72.2 \%$ \\
\hline Question 27 & 100 & 1 & 5 & 3.06 & $61.2 \%$ \\
\hline Question 28 & 100 & 1 & 5 & 2.98 & $59.6 \%$ \\
\cline { 3 - 7 } & & & & 3.51 & $70.2 \%$ \\
\cline { 5 - 7 }
\end{tabular}

\section{CONCLUSION}

Based on the research, can be concluded that first the average respondent assessed the use of online transportation in terms of service, application and it balanced scorecard was feasible. Second, Service and applications variables have a linear effect on it balanced scorecard. So, if the value of services and applications increases then the value of the balanced scorecard increases. Third, the IT Balanced scorecard value is used to help align IT and business, so that if you want to increase IT Balanced Scorecard, balanced scorecard can be improved on services and applications.

\section{ACKNOWLEDGMENT}

The author grateful to Magister Management, Universitas Komputer Indonesia for the support, so this research can be run. Author also would like to thankful to Grab for research object.

\section{REFERENCES}

[1] K. Philip., K.L. Kevin., “Marketing Management 14E,” New Jersey: Pearson Education. 2012

[2] ISO/ IEC, "Systems and Software Engineering - Systems and Software Quality Requirements and Evaluation (SQuaRE) - System and Software Quality Models," Switzerland : ISO Copyright. 2011

[3] J.D. Rohmad., J. Handaru., "Evaluasi Kualitas Aplikasi Mobile Kamus Istilah Jaringan Pada Platform Android DenganStandar ISO/ IEC 25010" Elinvo (Electronics, Informatics, and Vocational Education), Volume 2, Nomor 2, November 2017

[4] Gunardi, S.S. Dedi., S. Taryana, "Usulan Peta Strategis Teknologi Informasi Menggunakan Pendekatan Analisis Critical Success Factor (CSF) dan IT Balanced Scorecard," Majalah Ilmiah UNIKOM, Vol. 10, No.1, 2012

[5] W. Cindi, S.Y. Lin., A.A. Leon., "Analisa Tingkat Kepuasan Layanan TI (Studi Kasus Pada Aplikasi Gojek)", Teknologi Informasi dan Komunikasi ke-8 (SEMNASTIK 2016)

[6] A. Anal, S. Devadatta, "Assessing the Quality of M-Learning Systems using ISO/IEC 25010," International Journal of Advanced Computer Research (ISSN (print): 2249-7277 ISSN (online): 22777970), Volume 3, Number 3, 12 September-2013

[7] A. Nur, D. Albertus, V. Riantini, "The Classical Assumption Test to Driving Factors of Land Cover Change in The Development Region of Northern Part of West Java," The International Archives of the Photogrammetry, Remote Sensing and Spatial Information Sciences, Volume XLI-B6, 2016 XXIII ISPRS Congress, 12-19 July 2016 
[8] Arikunto, "Manajemen Penelitian," Jakarta: Rineka Cipta. 2009

[9] W. Ferronibah, "The Impact of Relationship Marketing on Customer Loyalty in a Private Bank", iBuss Management Vol. 2, No. 2, (2014) 50-59 